\title{
Effects of no Tillage and Various Tillage Methods on Yields of Maize, Field Beans and Pepper Grown on a Mollisol in Southern Puerto Rico'
}

\author{
H. M. Lugo-Mercado, J. Badillo-Feliciano and F. H. Ortiz-Alvarado ${ }^{2}$ \\ ABSTRACT
}

Corn, field beans and peppers were planted in a Mollisol at the Fortuna Research Center in $14 \times 6 \mathrm{~m}$ plots that were either not plowed, plowed twice or plowed four times at 15 or $45 \mathrm{~cm}$ depths, the same day or every 7 days. There were no statistical differences in corn and field bean yields between plowed or non-tilled plots. A similar response pattern was observed when the same test crops were planted in the same plots without disturbing the soil (residual effect). However, peppers showed a positive response when planted in plots that were plowed 4 times at $45 \mathrm{~cm}$ depth once every 7 days. These results indicate that corn, field beans and even peppers can be grown without tillage under the conditions prevailing at the Fortuna Research Center.

\section{INTRODUCTION}

In fiscal year 1981-82 the value of vegetables harvested in Puerto Rico amounted to $\$ 18.9$ million, whereas the value of the imported vegetables amounted to $\$ 30.8$ million (13). Therefore it is imperative that production levels be increased and that the traditionally high cost of production of these crops be reduced.

Since land preparation could account for $25 \%$ of total production costs and in view of current high costs of fuel and labor, it is necessary to carefully evaluate land preparation techniques $(4,6)$. Negative results of excessive tillage practices have also shown the need for innovation in regard to land preparation (5). The fact that tillage response varies with both crops and soils has been demonstrated by different researchers (1, $7,9,10,15)$.

Recent experiments at the Isabela and Corozal Substations showed that taniers responded positively to tillage (9). However, soil management trials in the mountain region, with and without tillage, revealed that taniers yield equally well under both treatments (1). Plantain seems to respond in a similar fashion, that is, a significant yield increase was obtained when the soil was tilled at Corozal whereas no significant differences were obtained when plowed and non-plowed plots were compared in Humatas, Quebrada and Los Guineos soils (7). Vicente-Chandler et al. (15), working with tobacco, sugarcane, plantains, taniers, yams,

${ }^{1}$ Manuscript submitted to Editorial Board September 12, 1983.

${ }^{2}$ Agronomists, Agronomy and Soils Department, Agricultural Experiment Station, Mayagüez Campus, University of Puerto Rico; and Assistant Agronomist, Horticulture Department, Agricultural Experiment Station, Mayagüez Campus, University of Puerto Rico, Mayagüez P. R. 
corn, and beans grown in clay soils of the mountain region of Puerto Rico, obtained good yields with no-tillage techniques. They concluded that in soils with excellent structure and good drainage it is not necessary to till. Likewise Lal (8), who compared tillage versus no tillage with crops such as corn, soybeans, cassava, pigeon peas and chick peas in Nigeria, obtained the best results in nonplowed plots. Moschler et al. (11) in Virginia, Triplett and Van-Doren (14) in Ohio, and Blevins (3) in Kentucky obtained better corn yields when the soils were not tilled than when they were plowed conventionally.

Subsoiling trials in Puerto Rico have produced different responses according to the crops and soils used. However, a positive response generally has been associated with subsoiling and the use of fertilizers or lime applications $(10,12)$.

It is well known that the frequency and intensity of land preparation depends largely on soil properties such as texture, structure, type of clay minerals, and soil compaction as well as on the crop to be grown. It is necessary, then, to critically examine tillage practices such as depth and frequency of plowing on the soil types prevalent in Puerto Rico.

\section{MATERIALS AND METHODS}

\section{EXPERIMENT}

An experiment was established November 1979 at the Fortuna Research and Development Center in which plots of $14 \times 6 \mathrm{~m}$ were either plowed twice or four times at 15 and $45 \mathrm{~cm}$ depths. Some plots were plowed the same day, whereas other plots were plowed every 7 days. Conventionally plowed plots were plowed once, left undisturbed for 2 weeks and plowed again before planting. An undisturbed (no tillage) plot was used as a control. The test crops, corn (Pioneer brand hybrid $\times 304$ C), peppers (cv. Blanco del Pais) and field beans (cv. Bonita) were planted in $6 \times 4 \mathrm{~m}$ sub-plots in a San Antón soil (Cumulic Haplustolls, fine-loamy, mixed, isohyperthermic) with a $\mathrm{pH}$ of 7.4 and a CEC of 25 meq/100 g of soil. The experimental design was a split-plot arrangement of randomized complete blocks, replicated four times, with land preparation methods assigned to main plots and test crops to subplots.

Corn and peppers were planted in rows $75 \mathrm{~cm}$ apart and $30 \mathrm{~cm}$ within the row; field beans were spaced $2.5 \mathrm{~cm}$ between plants and $75 \mathrm{~cm}$ between rows. Initially, all three crops were fertilized at a rate of 1,100 $\mathrm{kg} / \mathrm{ha}$ of a 10-10-8 fertilizer. Corn was sidedressed with urea at a rate of $50 \mathrm{~kg} / \mathrm{ha}$ at tasseling. Lasso (alachlor) $)^{3}$ at a rate of $2.4 \mathrm{~L} / \mathrm{ha}$ and Dacthal

\footnotetext{
${ }^{3}$ Trade names in this publication are used only to provide specific information. Mention of a trade name does not constitute a warranty of equipment or materials by the Agricultural Experiment Station of the University of Puerto Rico, nor is this mention a statement of preference over other equipment or materials.
} 
$80 \mathrm{~W}$ at $11 \mathrm{~kg} / \mathrm{ha}$ were used for corn and beans, respectively as preemergence herbicides. Insects and fungi were controlled with Diazinon AG 500 and Dithane M 45 at a rate of $1.25 \mathrm{l} / \mathrm{ha}$ and $2.5 \mathrm{~kg} / \mathrm{ha}$ respectively, when needed. The experiment was overhead irrigated as needed.

At harvest a recording penetrometer with a cone area of $0.04 \mathrm{~cm}^{2}$ was employed for resistance measurements in each plot. A soil sample from each plot was taken at the end of the experiment for moisture, $\mathrm{pH}, \mathrm{Ca}$, $\mathrm{Mg}, \mathrm{K}$ and $\mathrm{P}$ analysis as well as for organic matter and particle size determination as described by Black (2).

\section{0-81 EXPERIMENTS}

In November 1980, a second experiment was established at the same research site in which the same test crops (corn, field beans and peppers) were planted with varying tillage practices. The initial and residual effects of four soil treatments replicated four times were compared. A split-plot arrangement of randomized complete blocks was used. The soil treatments (main plots) were: undisturbed (no-tillage); plowed and harrowed 4 times at a 7 -day interval and $45 \mathrm{~cm}$ depth; plowed and harrowed 4 times at a 7-day interval and $15 \mathrm{~cm}$ depth; and plowed conventionally. This experiment (initial) was harvested in the spring of 1981. In October 1981, the same crops were planted in the same plots without further land preparation in order to measure the residual effect. Cultural practices were followed as stated above for the 1979 experiment. The residual effect experiment was harvested February 1982. Yields and chemical and physical analyses of the soil were recorded and statistically analyzed.

\section{RESULTS AND DISCUSSION}

\section{EXPERIMENT}

Table 1 shows yield data for beans, corn and pepper as a function of different land preparation methods. There were no differences in bean and corn yields from plots plowed in different manners or left undisturbed (no tillage). These results are in partial agreement with observations by Vicente-Chandler (15), Lal (8), Moschler (11), and others $(3,14)$. These researchers obtained equal or better yields when the soils were not tilled as when the soils were plowed conventionally. The absence of response to tillage correlates well with no differences in the penetrometer resistance measurements, and chemical analysis among the plowed and not plowed plots as shown in table 2 .

The response of peppers was somewhat similar to that of corn and beans, with the exception of the yield from plots plowed four times at 45 $\mathrm{cm}$ depth and at a 7 day interval, which yielded at a rate of $57,324 \mathrm{~kg} /$ ha, whereas the no-tillage plots yielded significantly less, $37,709 \mathrm{~kg} / \mathrm{ha}$. The $57,324 \mathrm{~kg} / \mathrm{ha}$ yield was significantly higher than those from other 
treatments. The pepper response is in agreement with data reported by Lugo and Badillo (9) with taniers (Xanthosoma spp.), an annual root crop. They obtained the highest yield when an Oxisol was plowed four times at a weekly interval. It appears that the longer the crop stays in the field the greater the sensitivity of the crop to the physical condition of the soil.

TABLE 1.-Field beans, corn and pepper yields for the 1979 experiment as affected by land preparation methods

\begin{tabular}{lccc}
\hline \multirow{2}{*}{ Treatments } & \multicolumn{3}{c}{ Yield } \\
\cline { 2 - 4 } & Field Beans & Corn & Peppers \\
\hline & & $\mathrm{kg} / \mathrm{ha}$ \\
1.--Undisturbed & $2127 \mathrm{a}^{1}$ & $5133 \mathrm{a}$ & $37709 \mathrm{a}$ \\
2.- Conventionally plowed & $2032 \mathrm{a}$ & $6199 \mathrm{a}$ & $46307 \mathrm{ab}$ \\
3.-Plowed 2 times, same day, 15 cm depth & $2127 \mathrm{a}$ & $5474 \mathrm{a}$ & $46301 \mathrm{ab}$ \\
4.-Plowed 2 times, same day, 45 cm depth & $2500 \mathrm{a}$ & $6275 \mathrm{a}$ & $39552 \mathrm{a}$ \\
5.-Plowed 2 times, 7-day interval, 15 cm depth & $2013 \mathrm{a}$ & $5701 \mathrm{a}$ & $41944 \mathrm{a}$ \\
6.-Plowed 2 times, 7-day interval, 45 cm depth & $2419 \mathrm{a}$ & $5227 \mathrm{a}$ & $46672 \mathrm{ab}$ \\
7.-Plowed 4 times, same day, 15 cm depth & $2089 \mathrm{a}$ & $5449 \mathrm{a}$ & $35328 \mathrm{a}$ \\
8.-Plowed 4 times, same day, 45 cm depth & $2216 \mathrm{a}$ & $4778 \mathrm{a}$ & $36445 \mathrm{a}$ \\
9.-Plowed 4 times, 7-day interval, 15 cm depth & $1983 \mathrm{a}$ & $5152 \mathrm{a}$ & $34369 \mathrm{a}$ \\
10.-Plowed 4 times, 7-day interval, 45 cm depth & $2229 \mathrm{a}$ & $6585 \mathrm{a}$ & $57324 \mathrm{~b}$ \\
\hline
\end{tabular}

${ }^{1}$ Means followed by the same letter do not differ statistically.

TABLE 2.-A comparison of some physical and chemical properties among treatments for the 1980-81 (residual effect) experiments

\begin{tabular}{|c|c|c|c|c|c|c|c|}
\hline \multirow[b]{2}{*}{ Treatments } & \multirow[b]{2}{*}{$\mathrm{pH}$} & \multirow{2}{*}{$\begin{array}{l}\text { Organic } \\
\text { matter }\end{array}$} & \multirow{2}{*}{$\begin{array}{l}\text { Resist- } \\
\text { ance }^{1} \text { to } \\
\text { penetra- } \\
\text { tion }\end{array}$} & \multicolumn{4}{|c|}{ Nutrients in the soil } \\
\hline & & & & $\mathrm{Ca}$ & $\mathrm{Mg}$ & $\mathrm{P}^{2}$ & $\mathrm{~K}$ \\
\hline & & $\%$ & $\mathrm{~kg} / \mathrm{cm}$ & \multicolumn{4}{|c|}{$p / m$} \\
\hline Undisturbed & 7.48 & 1.82 & 9.60 & 2514 & 498 & 25 & 382 \\
\hline Plowed 4 times to $15 \mathrm{~cm}$ & 7.54 & 1.72 & 9.57 & 2580 & 504 & 27 & 373 \\
\hline Plowed 4 times to $45 \mathrm{~cm}$ & 7.70 & 1.77 & 7.29 & 2459 & 499 & 24 & 386 \\
\hline \multirow[t]{2}{*}{ Conventionally plowed } & 7.36 & 1.74 & 7.30 & 2484 & 496 & 30 & 358 \\
\hline & $\mathrm{NS}^{3}$ & NS & NS & NS & NS & NS & NS \\
\hline
\end{tabular}

${ }^{1}$ Average of 3 determinations per plot at $15 \mathrm{~cm}$ depth.

${ }^{2}$ Olsen method.

${ }^{3}$ Not significant at the $5 \%$ probability level.

\section{0-81 EXPERIMENTS}

Table 3 shows corn, field beans and pepper yields for the initial (first crop) and residual effect (second crop) experiments. There were no significant differences among treatments in either experiment. However, it is evident that for the second pepper crop (residual effect experiment) the plowed plots outyielded the nontilled plots especially those plowed 
four times to $45 \mathrm{~cm}$ depth. This is in agreement with the results of the first crop and the data for the 1979 experiment (table 1). The observed lack of response to tillage by corn and beans reflects the good physical condition of the San Antón soil, as evidenced by low penetrometer readings, its relative high fertility (table 2 ) and the fact that the soil was irrigated weekly.

The above results clearly indicated that corn, field beans and even peppers can be grown in soils similar to San Antón without tillage and without reducing yield. Less tillage may permit the commercial production of corn, field beans and peppers because of reduced production costs.

TABLE 3.-Initial (1rst. crop) and residual (2nd. crop) land preparation effect on corn, field bean and pepper yields for the 1980-81 experiments

\begin{tabular}{lcccccc}
\hline & \multicolumn{6}{c}{ Yield (kg/ha) } \\
\cline { 2 - 7 } \multicolumn{1}{c}{ Treatments } & \multicolumn{2}{c}{ Corn } & \multicolumn{2}{c}{ Beans } & \multicolumn{2}{c}{ Peppers $^{1}$} \\
\cline { 2 - 8 } & 1rst. & 2nd. & 1rst. & 2nd. & 1rst. & 2nd. \\
& Crop & Crop & Crop & Crop & Crop & Crop \\
\hline Plowed 4 times to $15 \mathrm{~cm}$ & 7463 & 9920 & 2998 & 2236 & 53,196 & 60,000 \\
Plowed 4 times to $45 \mathrm{~cm}$ & 7236 & 9301 & 3305 & 2372 & 61,014 & 66,000 \\
Conventionally plowed & 6249 & 9961 & 2992 & 2406 & 51,643 & 61,500 \\
Undisturbed & 7358 & 9985 & 2786 & 1967 & 48,341 & 37,800 \\
\hline
\end{tabular}

${ }^{1}$ Yield calculated from per plant basis assuming 30,000 plants/ha.

\section{RESUMEN}

Se estudió el efecto de la preparación del suelo sobre el rendimiento de maiz, habichuela y pimiento en un suelo Mollisol, de la serie San Antón. Se comparó el efecto de arar dos o cuatro veces a profundidades de 15 ó $45 \mathrm{~cm}$ el mismo día o cada 7 días. Se utilizaron parcelas sin arar como control. Se comprobó que cultivos de corta duración en el campo, como maiz y habichuela, pueden sembrarse en este suelo sin que tenga que ararse previamente. Por otro lado, los rendimientos máximos de pimiento se obtuvieron cuando el suelo se aró cuatro veces a intervalo de 7 días a $45 \mathrm{~cm}$ de profundidad.

\section{LITERATURE CITED}

1. Abruña, F., Boneta, E. G., Vicente-Chandler, J. and Silva, S., 1967. Experiments on tanier production with conservation in Puerto Rico's mountain region, J. Agric. Univ. P.R. 51: 167-75.

2. Black, C. A., Ed, 1965. Methods of Soil Analysis. Parts 1 and 2. Agronomy 9:552-9, 900, 1149-76, Am. Soc. Agron., Madison, Wis.

3. Blevins, R., 1970. No tillage suitability to Kentucky soil. In Phillips, R., Thomas, G. and Blevins, R., Eds. No-tillage research: Research Reports and Reviews, University of Kentucky. pp. 8.

4. Frye, W., Walker, J. and Juncan, G., 1979. Comparison of energy requirements of no tillage and conventional tillage. In Phillips, R., Thomas, G. and Blevins, R., Eds. No 


\section{JOURNAL OF AGRICULTURE OF UNIVERSITY OF PUERTO RICO}

Tillage Research Reports and Reviews. University of Kentucky. pp. 76-83.

5. Gill, W. and Vanderberg, G., 1967. Soil Dynamics in tillage and traction, USDA Agricultural Handbook No. 316: 509-512.

6. González-Villafañe, E. and Espinet-Colón, G., 1975. Análisis económico de la producción de yautía en Puerto Rico en el 1972, Esta. Agric. Exp. Univ. P. R., Bull. 249.

7. Irizarry, H., Rivera, E., Rodriguez, J. A. and Green, J. J., 1978. Effect of planting pattern and population density on yield and quality of horn-type Maricongo plantain (Musa acuminata $\times$ M. balbisiana, AAB) in North Central Puerto Rico, J. Agric. Univ. P.R. 62:214-23.

8. Lal, R., 1979. No-tillage farming in the tropics. In Phillips, R., Thomas, C. and Blevins, R., Eds. No Tillage Research: Research Reports and Reviews. University of Kentucky. pp. 103-51.

9. Lugo-Mercado, H. M., Badillo-Feliciano, J. and López-Garcia, J., 1978. Effects of soil compaction on tanier yields, J. Agric. Univ. P.R. 62: 52-6.

10. Martinez, M. B. and Lugo-López, M. A. 1953. Influence of subsoil shattering and fertilization upon sugarcane and soil infiltration capacity, Soil Sci. 75: 307-15.

11. Moschler, W., Shear, G., Martens, D., Jones, G. and Willmowth, R., 1972. Comparative yield and fertilizer efficiency of notillage and conventionally tillage corn. Agron. J. 64(2): 229-31.

12. Pérez-Escolar, R., Lugo-López, M. A. and Scott, T. W., 1978. Effect of depth of lime application on yields and foliar composition of soybeans grown on a typical Ultisol of Puerto Rico, J. Agric. Univ. P. R. 62: 224-31.

13. Puerto Rico Department of Agriculture, 1982. Facts and Figures on Puerto Rico's Agriculture.

14. Triplett, G. and Van-Daren, D., 1969. Nitrogen, phosphorus and potassium fertilization on non-tilled maize. Agron. J. 61 (4): 636-39.

15. Vicente-Chandler, J., Costas, R. and Boneta, E., 1966. High crop yield produced with or without tillage on three typical soils on the humid region of Puerto Rico, J. Agric. Univ. P.R. 50 (2): 146-50. 